\title{
Structural Basis for Apoptosis Inhibition by Epstein-Barr Virus BHRF1
}

\author{
Marc Kvansakul $^{19 a a}$, Andrew H. Wei ${ }^{19 a b}$, Jamie I. Fletcher ${ }^{19 a c}$, Simon N. Willis ${ }^{1,2 a d}$, Lin Chen ${ }^{1,2}$, Andrew W. \\ Roberts $^{1,2}$, David C. S. Huang ${ }^{1,2 *}$, Peter M. Colman ${ }^{1,2 *}$
}

1 The Walter and Eliza Hall Institute of Medical Research, Parkville, Victoria, Australia, 2 Department of Medical Biology, University of Melbourne, Parkville, Victoria, Australia

\begin{abstract}
Epstein-Barr virus (EBV) is associated with human malignancies, especially those affecting the $B$ cell compartment such as Burkitt lymphoma. The virally encoded homolog of the mammalian pro-survival protein Bcl-2, BHRF1 contributes to viral infectivity and lymphomagenesis. In addition to the pro-apoptotic BH3-only protein Bim, its key target in lymphoid cells, BHRF1 also binds a selective sub-set of pro-apoptotic proteins (Bid, Puma, Bak) expressed by host cells. A consequence of BHRF1 expression is marked resistance to a range of cytotoxic agents and in particular, we show that its expression renders a mouse model of Burkitt lymphoma untreatable. As current small organic antagonists of Bcl-2 do not target BHRF1, the structures of it in complex with Bim or Bak shown here will be useful to guide efforts to target BHRF1 in EBV-associated malignancies, which are usually associated with poor clinical outcomes.
\end{abstract}

Citation: Kvansakul M, Wei AH, Fletcher Jl, Willis SN, Chen L, et al. (2010) Structural Basis for Apoptosis Inhibition by Epstein-Barr Virus BHRF1. PLoS Pathog 6(12): e1001236. doi:10.1371/journal.ppat.1001236

Editor: Jae U. Jung, University of Southern California School of Medicine, United States of America

Received July 19, 2010; Accepted November 22, 2010; Published December 23, 2010

Copyright: (c) 2010 Kvansakul et al. This is an open-access article distributed under the terms of the Creative Commons Attribution License, which permits unrestricted use, distribution, and reproduction in any medium, provided the original author and source are credited.

Funding: Our work is supported by grants and fellowships from the Australian NHMRC (Program Grants 461219 \& 461221; Project Grant 637336; Fellowships to AWR, DCSH, MK, PMC; IRIISS grant 361646), NIH (CA80188; CA43540), Leukemia \& Lymphoma Society (SCOR grant 7413-07; Fellowship to MK), Sylvia \& Charles Viertel Charitable Foundation (Fellowship to DCSH), Cancer Council of Victoria (Fellowships to PMC), the Leukemia Foundation (Fellowship to AHW), the Australian Cancer Research Foundation and the Victorian State Government (OIS grant). The funders had no role in study design, data collection and analysis, decision to publish, or preparation of the manuscript.

Competing Interests: The authors have declared that no competing interests exist.

*E-mail: huang_d@wehi.edu.au (DCSH); pcolman@wehi.edu.au (PMC)

9 These authors contributed equally to this work.

a Current address: Department of Biochemistry, La Trobe University, Victoria, Australia

ab Current address: Department of Clinical Hematology, The Alfred Hospital and the Australian Centre for Blood Diseases, Monash University, Melbourne, Australia ac Current address: Children's Cancer Institute Australia for Medical Research, Randwick, New South Wales, Australia

ad Current address: Departments of Neurology, Brigham \& Women's Hospital and Harvard Medical School, Boston, Massachusetts, United States of America

\section{Introduction}

To combat invading viruses, altruistic suicide of the infected host cells may be initiated to rapidly and efficiently eliminate the pathogen $[1,2]$. Often, this response is a critical component of host defences $[1,2]$. Consequently, many viruses have co-evolved adaptive mechanisms to subvert apopt osis, thereby ensuring their own survival and propagation. Some viruses, such as Epstein-Barr virus (EBV), encode homologs of the mammalian pro-survival protein Bcl-2 [3,4,5]. EBV was first identified in association with Burkitt lymphoma and it is also linked to other lymphoid malignancies (Hodgkin's lymphoma, post-transplant lymphoproliferative disorders) and nasopharyngeal carcinoma [6]. Whereas increased expression of Bcl-2 promotes malignancies such as human follicular lymphoma [7], the precise role of the EBV encoded Bcl-2 homolog BHRF1 in EBV-associated malignancies is less well defined.

However, more recent studies link BHRF1 to the transformation of primary B lymphocytes [8] and to lymphomagenesis [9]. Since overactivity of the oncogene $m y c$ is obligatory for Burkitt lymphoma $[10,11,12]$, expression of BHRF1 may be necessary to block $m y c$-induced apoptosis, akin to the striking synergy observed between Bcl-2 and myc during B cell transformation [13,14]. Of note, the constitutive expression of BHRF1 permits lymphoblastoid immortalization by EBV and their prolonged survival [9], and together with expression of BHRF1 during normal B cells transformation [8] suggests a role for BHRF1 in post-transplant lymphoproliferative disease. Although confirmed BHRF1 expression has been shown in only a subset of Burkitt lymphomas [9,15], it is plausible that BHRF1 plays a central role in the maintenance of this subset of Burkitt lymphomas as Bcl-2 overexpression is rare in this disease.

As BHRF1 may be central for developing and maintaining certain EBV-associated lymphomas, we investigated if BHRF1 can modulate responses to therapy in experimental models. If so, BHRF1 represents an attractive drug target since normal cells may well be spared by its selective antagonism. Here, we show that BHRF1 potently confers chemoresistance, and importantly, it adversely impacts upon survival in a mouse model of Burkitt lymphoma. BHRF1 acts by sequestering a subset of the proapoptotic Bcl-2 family proteins; we show here the 3D structures of it in complex with $\mathrm{BH} 3$ domains of two, Bim and Bak, which may provide the basis for developing small molecule inhibitors of BHRF1 to improve the generally poor prognosis in EBVassociated malignancies. 


\section{Author Summary}

Altruistic suicide of infected host cells is a key defense mechanism to combat viral infection. To ensure their own survival and proliferation, certain viruses, including Epstein-Barr virus (EBV), have mechanisms to subvert apoptosis, including the expression of homologs of the mammalian pro-survival protein Bcl-2. EBV was first identified in association with Burkitt lymphoma and it is also linked to certain Hodgkin's lymphomas and nasopharyngeal carcinoma. Whereas increased expression of $\mathrm{Bcl}-2$ promotes malignancies such as human follicular lympho$\mathrm{ma}$, the precise role of the EBV encoded $\mathrm{Bcl}-2$ homolog BHRF1 in EBV-associated malignancies is less well defined. BHRF1 is known to bind the pro-apoptotic BH3-only protein Bim, and here we demonstrate that it also binds other pro-apoptotic proteins (Bid, Puma, Bak) expressed by host cells. Crystal structures of BHRF1 with the $\mathrm{BH} 3$ regions of Bim and Bak illustrate these interactions in atomic detail. A consequence of BHRF1 expression is marked resistance to a range of cytotoxic agents, and we show that its expression renders a mouse model of Burkitt lymphoma untreatable. As current antagonists of $\mathrm{Bcl}-2$ do not target BHRF1, our crystal structures will be useful to guide efforts to target BHRF1 in EBV-associated malignancies, which are usually associated with poor clinical outcomes.

\section{Results/Discussion}

\section{BHRF1 counters apoptosis induced by multiple chemotherapeutic agents}

Using cultured cell lines, we tested the ability of BHRF1 to confer resistance against a range of apoptotic stimuli, especially those used for cancer chemotherapy. Stable expression of BHRF1 in FDC-P1 mouse myelomonocytic cells conferred resistance to etoposide or $\gamma$-irradiation (Fig. 1A) comparable to that observed in cells expressing similar levels of Bcl-2, Bcl- $\mathrm{x}_{\mathrm{L}}$ or Bcl-w (Fig. 1D). It also inhibited apoptosis induced by other cytotoxics including cytosine arabinoside (Ara-C), doxorubicin, etoposide and staurosporine in other cell lines (Figs. 1B, 1C, S1 and data not shown), comparable to that observed in cells expressing similar levels of Bcl-2 (Fig. 1E). Thus, BHRF1, like its mammalian counterparts, inhibits apoptosis induced in multiple cell types by diverse chemotherapeutic agents.

\section{BHRF1 preserves mitochondrial function by inhibiting the activation of Bax and Bak}

To ascertain precisely how BHRF1 interferes with apoptosis signaling, we examined mitochondrial outer membrane permeabilization (MOMP) [16] in FDC-P1 cells after treatment with staurosporine. Whereas MOMP occurred rapidly in the parental cells, as indicated by the reduced uptake of the mitochondrial dye $\mathrm{DiOC}_{6}(3)$, it was inhibited in cells expressing BHRF1 or Bcl-2 (Fig. 2A), implicating an anti-apoptotic effect upstream of mitochondrial damage. When the mediators of mitochondrial damage (Bax and Bak) were examined, we found that BHRF1 inhibited translocation of Bax from the cytosol (Fig. 2B) and activation of Bax and Bak was abrogated, as their conformational alteration associated with activation is blocked (Fig. 2C). Consistent with these observations, BHRF1 also inhibited the release of cytochrome $c$ from within the mitochondria (Fig. 2B).

We conclude that BHRF1 must exert its anti-apoptotic effect at the level of, or prior to, Bax and Bak activation, consistent with a report that BHRF1 prevented Bax and Bak conformational change, oligomerization and activation of the initiator caspase, caspase-9 [17]. How then might BHRF1 inhibit activation of these essential cell death mediators?

\section{BHRF1 interacts with a sub-set of pro-apoptotic Bcl-2 family proteins}

It is most likely that BHRF 1 acts to abort cell death initiation by sequestering the endogenous pro-apoptotic mammalian Bcl-2 family members. Thus, we assessed the ability of a recombinant C-terminally truncated form of BHRF1 to directly bind peptides spanning the $\mathrm{BH} 3$ domains of pro-apoptotic Bcl-2 proteins using isothermal titration calorimetry (ITC). Binding was observed with peptides from the $\mathrm{BH} 3$-only proteins Bim $\left(\mathrm{K}_{\mathrm{D}}=18 \mathrm{nM}\right)$, Puma $(70 \mathrm{nM})$ or Bid $(110 \mathrm{nM})$ (Fig. 3A). No detectable binding was observed with peptides from other $\mathrm{BH}$ only proteins, or with Mule and Beclin-1, other proteins harboring a BH3 domain. We confirmed the interaction of intact BHRF1 in mammalian cells with selected full-length $\mathrm{BH} 3$-only proteins in coimmunoprecipitation assays (Fig. 3B). These results closely mirror those obtained in solution competition assays, using either fluorescence polarization [18] or surface plasmon resonance [19]. Thus, BHRF1 probably antagonizes a subset of the BH3only proteins by direct sequestration. Interestingly, the ones targeted (Bid, Bim, Puma) are potent inducers of apoptosis, either because they neutralize most, if not all, the mammalian prosurvival proteins $[20,21]$ or because they can directly activate Bax or Bak $[22,23,24]$.

We also investigated if BHRF1, in a manner similar to some mammalian [21,25] and viral Bcl-2 proteins [26,27], might directly bind $\mathrm{Bax}$ and $\mathrm{Bak}$, the downstream mediators of mitochondrial damage. Recombinant BHRF1 bound a 26-mer Bak BH3 peptide $\left(\mathrm{K}_{\mathrm{D}}=150 \mathrm{nM}\right)$, but only weakly $(>1 \mu \mathrm{M})$ to Bax BH3 (Fig. 3A). Consistent with the binding data, we observed that BHRF1 could directly counter Bak (Fig. 3C), but not Bax, when these proteins were expressed in yeast [28]. This heterologous model system is suited for studying the functional interactions by circumventing potential complications due to the presence of endogenous Bcl-2 family proteins in mammalian cells and avoids the use of detergents that may artificially induce or disrupt interactions between Bcl-2 family proteins [29]. Our assay is based on the observation that overexpression of Bax or Bak in yeast is lethal, even though yeasts do not express Bcl-2 family members and do not undergo apoptosis. Nonetheless, co-expression of Bcl-2, Bcl- $\mathrm{x}_{\mathrm{L}}, \mathrm{Mcl}-1$, or Al with Bax and Bak can suppress death induced in yeast [30], thus reconstituting key aspects of the mammalian apoptotic machinery. Our observation that BHRF1 could counter Bak (Fig. 3C), but not Baxinduced yeast death when these proteins were expressed in yeast suggests that BHRF1 is only able to directly neutralize Bak, but not Bax.

Taken together with the previous reports that BHRF1 interacts with the full-length Bak, but not with Bax [17,31,32], we conclude that BHRF1 can keep Bak inactive by direct binding (Fig. 3A, 3C, [19]), but must inhibit Bax indirectly, presumably by its ability to sequester BH3-only proteins such as Bim (Fig. 3A, 3B, [31]). It will therefore be interesting to investigate which pro-apoptotic protein is the critical target for BHRF1 in diverse cell types, especially those targeted by EBV during oncogenesis. It is noteworthy that in some lymphoid cells, the pro-survival action of BHRF1 tracked with its ability to bind Bim [31], which is critical for apoptosis induced by multiple stimuli in this cell type [33] and plays a role in suppressing myc-driven lymphomagenesis [34]. 
A
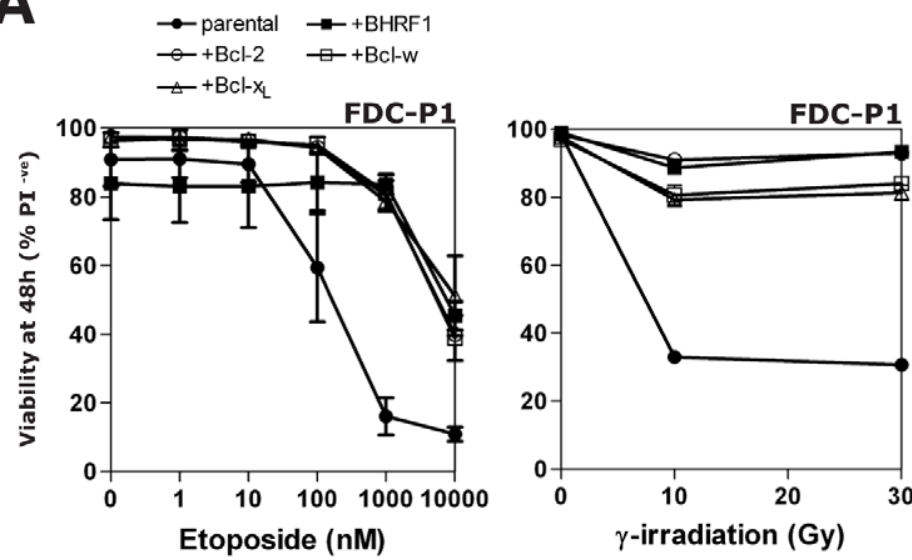

B

C
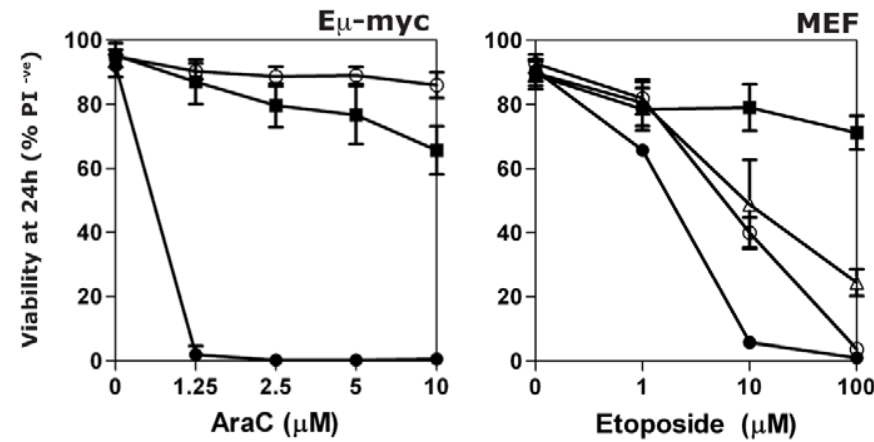

D

$\mathbf{E}$
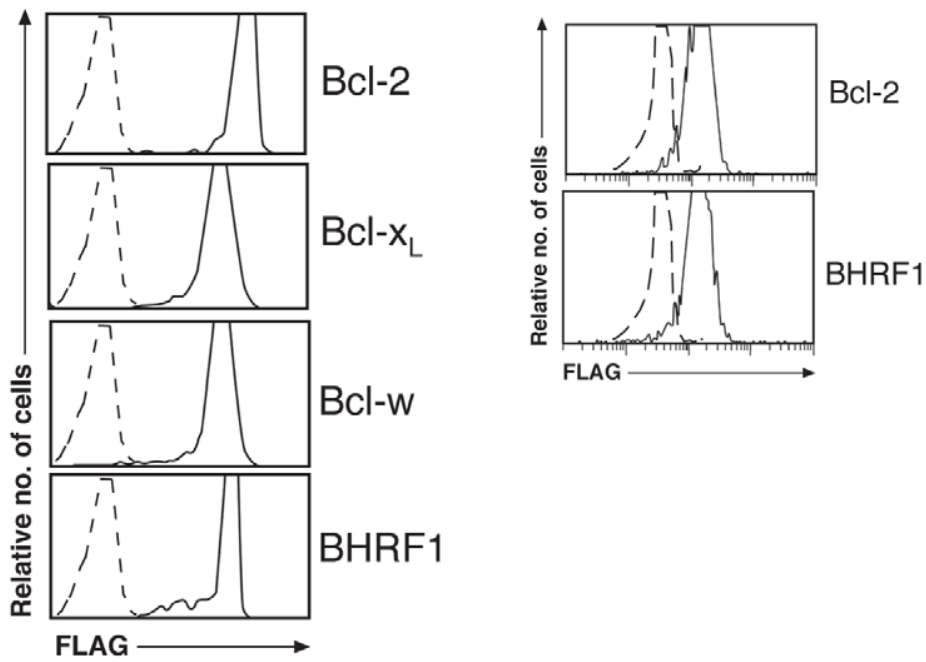

Figure 1. BHRF1 protects cells from diverse apoptotic stimuli. (A) Viability of FDC-P1 cells stably overexpressing $B H R F 1, B C l-2, B C l-x_{L}, B C l-w$ or vector, treated with 0-10 $\mu \mathrm{M}$ etoposide (left) or 0-30 Gy $\gamma$-irradiation (right) and cultured for $48 \mathrm{~h}$. (B) E $\mu$-myc pre-B-cell tumor cells were stably transfected with BHRF1, BCl-2 or vector were exposed to 0-10 $\mu \mathrm{M}$ cytosine arabinoside (Ara-C) for $24 \mathrm{~h}$. (C) MEFs overexpressing BHRF1, BCl-2, Bcl- $\mathrm{x}_{\mathrm{L}}$ or vector were treated with $0-100 \mu \mathrm{M}$ etoposide for $24 \mathrm{~h}$. (D) Bcl-2, Bcl- $x_{\mathrm{L}}, \mathrm{BCl}-\mathrm{w}$ and BHRF1 are expressed at comparable levels in FDC-P1 cells. FLAGtagged wild-type $\mathrm{BCl}-2, \mathrm{BCl}-\mathrm{x}_{\mathrm{L}}, \mathrm{BCl}-\mathrm{W}$ and BHRF1 were stably expressed in FDC-P1 cells. Protein expression was evaluated using flow cytometry after staining fixed cells with an anti-FLAG antibody, followed by an anti-mouse FITC secondary antibody. Controls (dotted lines) indicate staining of cells expressing empty vector. (E) BHRF1 and Bcl-2 are expressed at comparable levels in E $\mu$-myc pre-B-cell tumor cells. Pre-B-cell tumor cells derived from E $\mu$-myc transgenic mice were stably transfected with FLAG-tagged BHRF1, Bcl-2 or an empty control vector. Protein expression was evaluated using flow cytometry after staining fixed cells with an anti-FLAG antibody, followed by an anti-mouse FITC secondary antibody. Controls (dotted lines) indicate staining of cells expressing empty vector. Cell viability was determined by PI exclusion; data shown are means \pm 1 SEM of 3 independent experiments except for the representative $\gamma$-irradiation experiment shown in (A).

doi:10.1371/journal.ppat.1001236.g001 
A

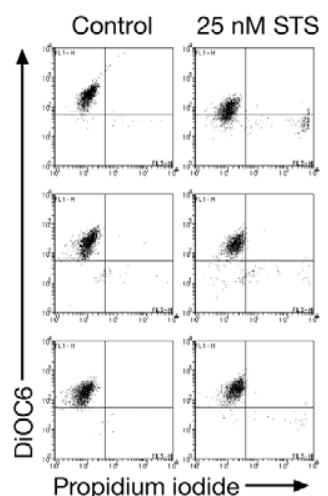

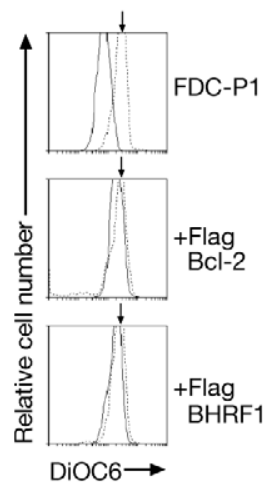

B

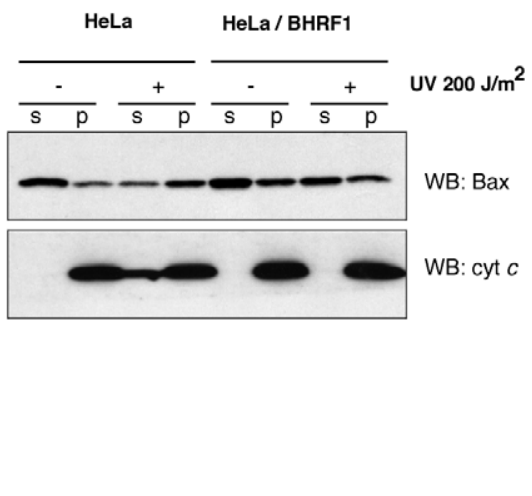

C

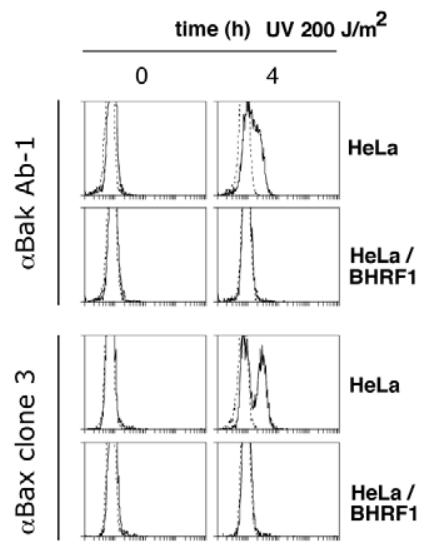

Figure 2. BHRF1 inhibits loss of mitochondrial transmembrane potential and Bax/Bak activation. (A) FDC-P1 cells expressing BHRF1, BCl2 or a control vector were treated with $25 \mathrm{nM}$ staurosporine for $24 \mathrm{~h}$. Outer mitochondrial transmembrane potential $\left(\Delta \psi_{\mathrm{m}}\right)$ was assessed by DiOC $6(3)$ uptake. (B) HeLa cells treated with $200 \mathrm{~J} / \mathrm{m}^{2}$ UV-irradiation were analyzed at $4 \mathrm{~h}$ for Bax translocation and cytochrome $c$ release by immunoblotting after fractionation into soluble (s) and pellet (p) fractions. (C) Bax and Bak activation in UV-irradiated HeLa cells were assessed at $4 \mathrm{~h}$ using the conformation-specific mouse anti-Bak clone Ab-1 (Calbiochem) or mouse anti-Bax clone 3 antibodies [53].

doi:10.1371/journal.ppat.1001236.g002

A

$\begin{array}{ll}\text { Ligand } & \mathbf{K}_{\mathbf{D}} \text { (nM) } \\ \text { (hs)Bad } & \mathrm{NB} \\ \text { (hs)Bid } & 110 \pm 1 \\ \text { (hs)Bik } & \mathrm{NB} \\ \text { (hs)Bim } & 18 \pm 2 \\ \text { (mm)Bmf } & \mathrm{NB} \\ \text { (mm)Hrk } & \mathrm{NB} \\ \text { (hs)Noxa } & \mathrm{NB} \\ \text { (hs)Puma } & 70 \pm 4 \\ \text { (mm)Mule } & \mathrm{NB} \\ \text { (mm)Beclin } & \mathrm{NB} \\ \text { (hs)Bak } & 150 \pm 69 \\ \text { (hs)Bax } & 1400 \pm 180\end{array}$

B

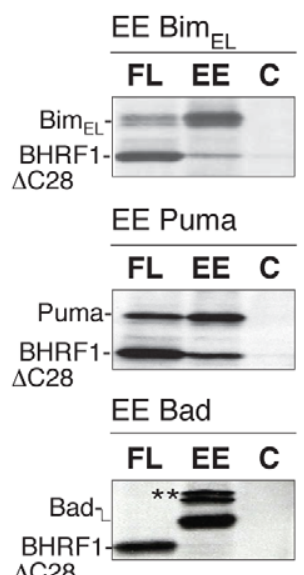

C

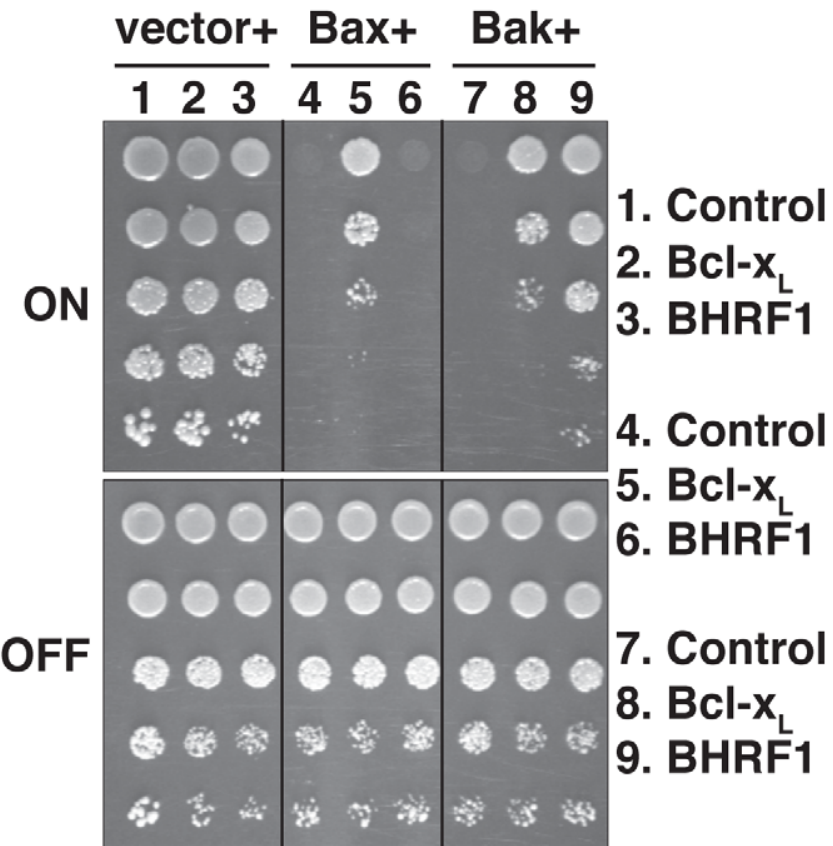

Figure 3. BHRF1 binds a subset of pro-apoptotic Bcl-2 family proteins to counter apoptosis. (A) The affinity of recombinant BHRF1 $\Delta \mathrm{C} 31$ for $\mathrm{BH} 3$ domain peptides (26-mers, except for a Bax 28-mer and a Bid 34-mer) was assessed using isothermal titration calorimetry (ITC). $\mathrm{K}_{\mathrm{d}}$ values (in $\mathrm{nM})$ are the means of 3 experiments \pm SD. NB: no binding detected. (B) Lysates prepared from ${ }^{35}$ S-labeled HEK-293T cells co-expressing FLAG-tagged BHRF1 and EE-tagged BH3-only proteins were immunoprecipitated with mouse monoclonal antibodies recognizing the FLAG (FL), EE, or an irrelevant control (C) tag. **Endogenous 14-3-3 associating with Bad [56]. (C) Yeast co-transformed with constructs encoding Bax or Bak and the indicated prosurvival proteins, each under the control of an inducible (GAL) promoter, were spotted onto inducing galactose ("ON") or repressing glucose ("OFF") plates as 5-fold serial dilutions. Images are representative of 2 independent experiments.

doi:10.1371/journal.ppat.1001236.g003 
Structural basis for the engagement of $\mathrm{BH} 3$ domains by BHRF1

Our data (Fig. 3) and previously published studies [18] suggest that BHRF1, like its mammalian counterparts, inhibits cell death by sequestering endogenous pro-apoptotic Bcl-2 proteins. However, the structural basis for this is unclear since a previously published structure of C-terminally truncated BHRF1 lacked the characteristic hydrophobic surface groove responsible for interaction with the $\mathrm{BH} 3$ domains [35]. We have therefore determined crystal structures of BHRF1 in complex with its key targets, the BH3 domains of Bim (Fig. 4A-B, Table 1) and Bak (Fig. 4C, Table 1).

The Bim BH3 peptide binds into a surface groove formed by helices $\alpha 2-5$ of BHRF1 (Fig. 4A), in a similar manner to that previously observed for mammalian pro-survival Bcl-2 members such as Bcl- $\mathrm{x}_{\mathrm{L}}$ [36] or the unrelated viral Bcl-2 protein M1 1L [27]. Bak BH3 binds in an equivalent manner (Fig. 4C), and the two complexes superimpose with an RMSD of only $0.6 \AA$ over the entire BHRF1 backbone indicating their similarities. As the characteristic hydrophobic surface groove was absent in unliganded BHRF1 due to the close proximity of helices $\alpha 3$ and $\alpha 4$ (Fig. 4E; [35]), significant structural changes are required in order to accommodate Bim or Bak BH3 domains. These changes affect mainly $\alpha 4$, which is at a $120^{\circ}$ angle to $\alpha 3$ in the BH3-bound form (Fig. 4A), compared to the near anti-parallel alignment in the free form (Fig. 4E). Overall, the free and bound BHRF1 structures (comparing Fig. 4A with 4B) superimpose with an RMSD of $3.5 \AA$, with most differences found within the BH3 binding groove. This is reminiscent of the movement observed in $\mathrm{Bcl}-\mathrm{x}_{\mathrm{L}}$, which in the ligand-free state displays a narrow binding groove [37]. However, upon ligand binding, both $\alpha 3$ and 4 helices move to widen the hydrophobic groove and allow binding [36]. In contrast, the movement of $\alpha 3$ that enables groove opening in BHRF1 upon ligand binding is much less pronounced.

The side-chain interactions contributing to the BHRF1-BH3 complexes are equivalent to those observed for mammalian prosurvival proteins such as $\mathrm{Bcl}-\mathrm{x}_{\mathrm{L}}$, with the four conserved hydrophobic BH3 residues of $\mathrm{Bim}$ (I58, L62, I65 and F69; numbering based on human Bim $_{\mathrm{L}}$ ) protruding into pockets within the BHRF1 hydrophobic binding groove (Fig. 4G). Similarly, Bak residues V74, L78, I81 and I85 (numbering based on human Bak) interact with the BHRF1 binding groove (Fig. $4 \mathrm{H})$. In addition to the hydrophobic interactions, BHRF1 R100 forms a salt bridge with Bim D67 or with Bak D83 (Fig. 4G, 4H). This electrostatic interaction is also observed in complexes of Mcl-1 and Bcl- $\mathrm{x}_{\mathrm{L}}$ with pro-apoptotic $\mathrm{BH} 3$ domains $[36,38]$ and even in a complex of Bcl-
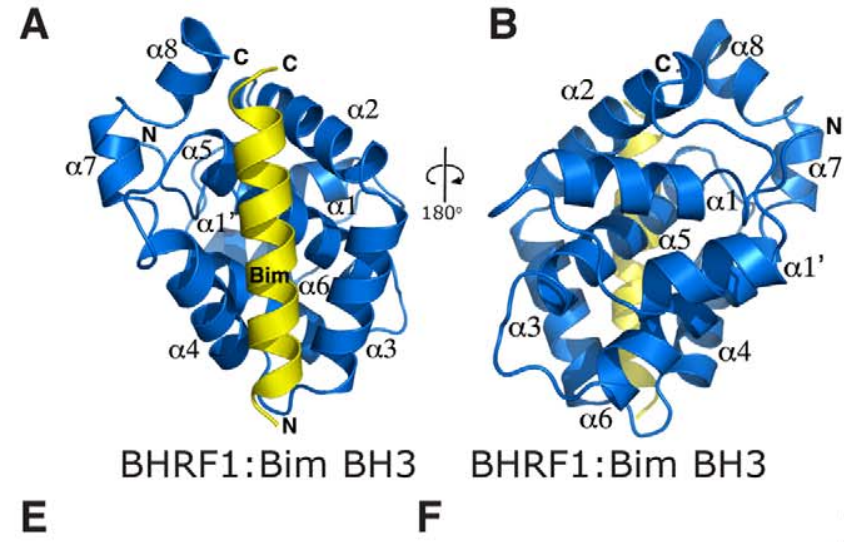

BHRF1:Bim BH3

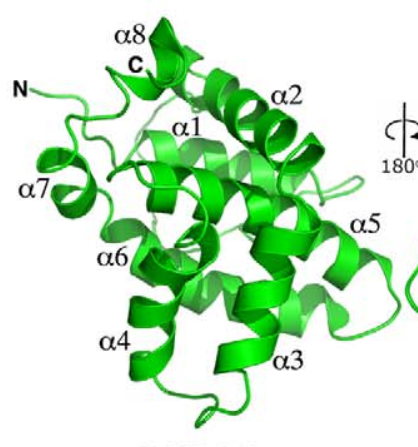

BHRF1

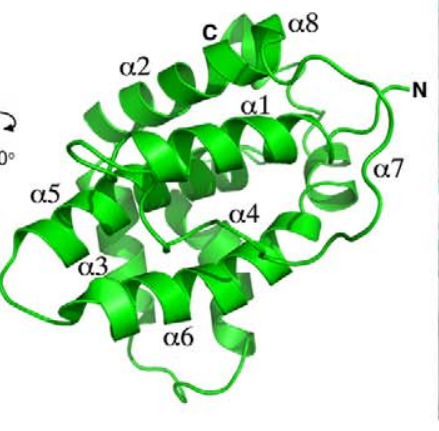

BHRF1

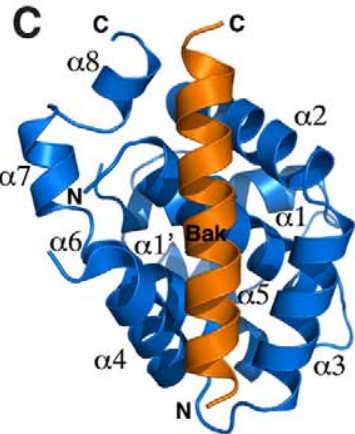

BHRF1:Bak BH3

G

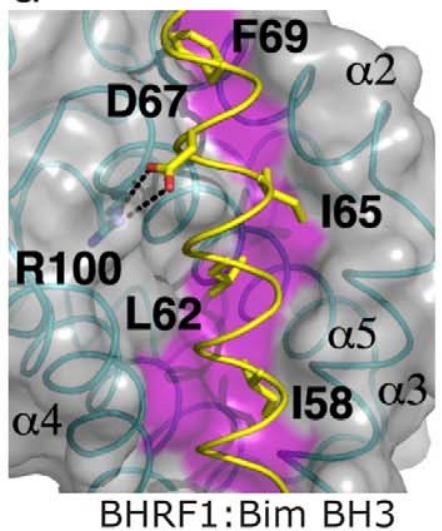

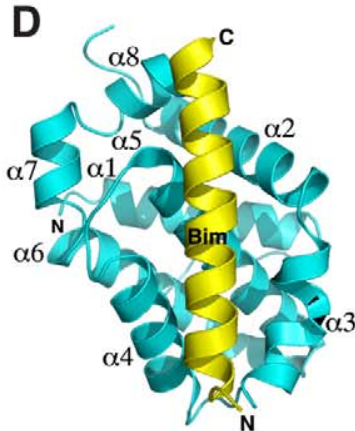
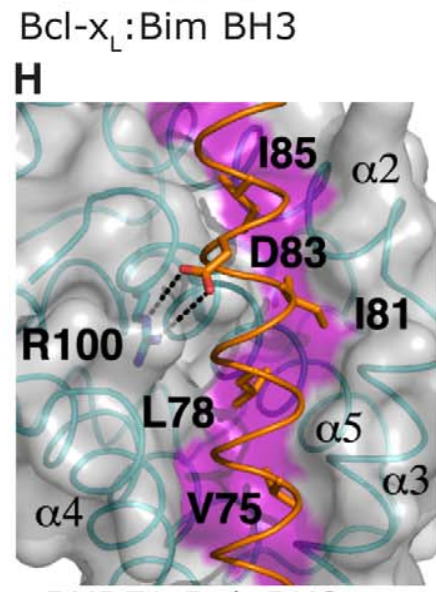

BHRF1:Bak BH3

Figure 4. BH3 peptides bind BHRF1 in a canonical binding groove. (A-B) BHRF1 (blue) in complex with the Bim $\mathrm{BH} 3$ domain (yellow). $\mathrm{BHRF} 1$ helices are labeled $\alpha 1, \alpha 1^{\prime}, \alpha 2-8$. The view in $(A)$ is into the hydrophobic binding groove formed by helices $\alpha 3-5$, while (B) is rotated by $180^{\circ}$ through the vertical axis to illustrate helix $\alpha 1^{\prime}$. (C) BHRF1 (blue) in complex with the Bak BH3 domain (orange). The view is as in (A). (D) Bcl- $x_{L}$ (cyan) in complex with the Bim BH3 domain [36]. The view is as in (A). (E-F) Unliganded BHRF1 ([35]; in green). The view in (E) is similar to (A), while (F) is comparable to (B). The binding groove is occluded by the near parallel arrangement of helices $\alpha 3$ and $\alpha 4$. (G) Detailed view of the BHRF1:Bim complex interface. The BHRF1 surface, backbone and binding groove are shown in grey, cyan and magenta respectively, while Bim BH3 is shown in yellow. The four key hydrophobic residues of Bim (I58, L62, 165 and F69; numbering based on human Bim ${ }_{\mathrm{L}}$ ) protruding into the binding groove, as well as the conserved salt-bridge formed by Bim D67 and BHRF1 R100 are labeled. $(\mathrm{H})$ Detailed view of the BHRF1:Bak complex interface. Colour scheme is as for (G) with Bak BH3 shown in orange. The four key hydrophobic residues of Bak (V75, L78, I81 and I85) protruding into the BHRF1 binding groove, as well as the conserved salt-bridge formed by Bak D83 and BHRF1 R100 are labeled.

doi:10.1371/journal.ppat.1001236.g004 
Table 1. Crystallographic statistics.

\begin{tabular}{|c|c|c|c|}
\hline Crystal & BHRF1:Bim BH3 & BHRF1:Bim BH3 & BHRF1:Bak BH3 \\
\hline Data collection and phasing & Derivative $\mathrm{MeHg}$ & Native & Native \\
\hline Spacegroup & $\mathrm{P}_{2} 21$ & $P 3_{2} 21$ & $P 3_{2} 21$ \\
\hline Resolution range $(\AA)$ & $50-2.7$ & $50-1.5$ & $50-2.05$ \\
\hline Unique reflections & 6110 & 33924 & 13668 \\
\hline Multiplicity ${ }^{a}$ & $7.2(5.5)$ & $9.6(6.7)$ & $10.0(5.1)$ \\
\hline Completeness (\%) ${ }^{a}$ & $99.1(94.3)$ & $98.8(93.1)$ & $99.5(95.8)$ \\
\hline l/øl & & $40.7(2.4)$ & $33.9(2.2)$ \\
\hline $\mathrm{R}_{\text {merge }}{ }^{a, b}$ & $0.088(0.346)$ & $0.043(0.568)$ & $0.064(0.497)$ \\
\hline $\mathrm{R}_{\text {deriv }}{ }^{c}$ & 0.212 & & \\
\hline $\mathrm{R}_{\text {cullis }}$ (centric/acentric) ${ }^{d}$ & $0.653 / 0.609$ & & \\
\hline Phasing power (centric/acentric) ${ }^{\text {e }}$ & $1.46 / 1.39$ & & \\
\hline \multicolumn{4}{|l|}{ Refinement } \\
\hline Resolution range $(\AA)$ & & $50-1.5$ & $20-2.05$ \\
\hline Reflections (working set/test set) & & $32174 / 1705$ & $12945 / 668$ \\
\hline Protein atoms & & 1466 & 1437 \\
\hline Solvent atoms & & $116 \mathrm{H}_{2} \mathrm{O}, 9 \mathrm{Br}$ & $73 \mathrm{H}_{2} \mathrm{O}, 4 \mathrm{NO}_{3}$ \\
\hline$R_{\text {cryst }} / R_{\text {free }}{ }^{f}$ & & $0.198 / 0.205$ & $0.184 / 0.217$ \\
\hline r.m.s.d. bonds $(\AA)$ & & 0.015 & 0.021 \\
\hline r.m.s.d. angles ( ${ }^{\circ}$ ) & & 1.7 & 1.8 \\
\hline Ramachandran plot (\%) ${ }^{\mathrm{g}}$ & & $95.0 / 5.0 / 0.0 / 0.0$ & $97.4 / 1.9 / 0.6 / 0.0$ \\
\hline \multicolumn{4}{|c|}{ 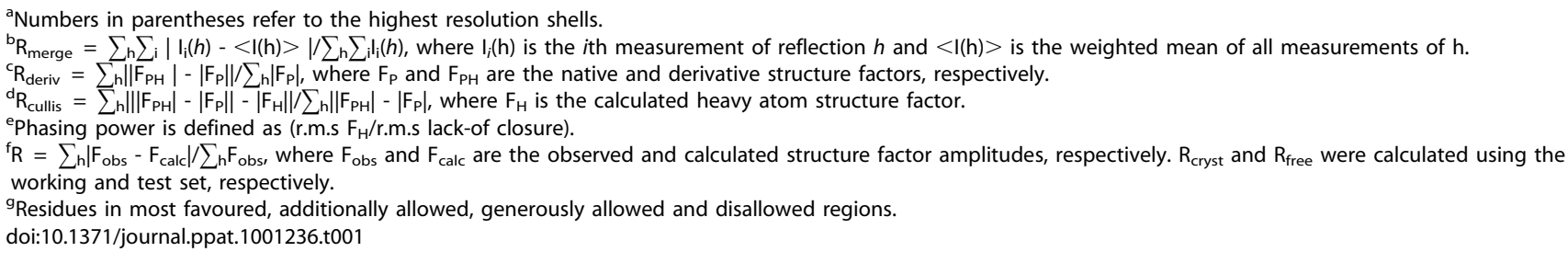 } \\
\hline
\end{tabular}

$\mathrm{x}_{\mathrm{L}}$ with a peptide foldamer [39]. The conservation of aspartic acid in the mammalian BH3 ligands suggests that this interaction is of particular importance for complex formation, and indeed a BHRF1 R100A mutation reduces Bim binding and abolishes interaction with Bak [31].

\section{BHRF1 confers potent chemoresistance in vivo}

Since BHRF1 engages BH3 domains using a hydrophobic groove (Fig. 4) in a manner equivalent to that of its mammalian counterparts, conserving key interactions, we asked whether ABT737, a BH3 mimetic compound known to inhibit Bcl-2, Bcl- $\mathrm{x}_{\mathrm{L}}$, and Bcl-w [40,41], could also target BHRF1. In the absence of prosurvival Mcl-1, ABT-737 is a potent cytotoxic agent. However, cells expressing BHRF1 were completely insensitive to ABT-737, even at the highest dose tested $(10 \mu \mathrm{M})$ (Fig. S2), and survived long-term (Fig. 5A). Similarly, recombinant BHRF1 did not bind ABT-737 in biosensor assays $\left(\mathrm{IC}_{50}>20 \mu \mathrm{M}\right.$, data not shown). As ABT-737 is ineffective and as BHRF1 can potently confer chemoresistance when tested in cultured cell lines (Fig. 1), we evaluated the impact of its expression in a transgenic mouse model of Burkitt lymphoma [11]. In the E $\mu$-myc mouse, myc is overexpressed in the B cell and drives an aggressive B cell leukemia/lymphoma syndrome that is very similar to human Burkitt lymphoma.

Malignant cells derived from sick $\mathrm{E} \mu-m y c$ mice are readily transplantable into syngeneic wild-type recipients which succumb within four weeks to a disseminated disease if left untreated [42].
Treatment with Ara-C (Fig. 5C, black line), an agent used in the clinic for treating patients with Burkitt lymphoma, resulted in a sustained disease remission and survival with all mice alive and disease-free at 100 days with normal peripheral blood counts and spleen weights. In striking contrast, only a handful of treated mice that were inoculated with tumor cells overexpressing BHRF1 or Bcl-2 survive long-term (Fig. 5C). Comparable results were observed when two other cytotoxic agents, cyclophosphamide and etoposide, were used in similar efficacy studies (data not shown). Therefore BHRF1, like Bcl-2 [42], can potently confer chemoresistance in a mouse model of Burkitt lymphoma. Thus, it is highly likely that expression of BHRF1 will attenuate the response during treatment for EBV-driven malignancies.

\section{Concluding remarks}

In this study, we have confirmed that EBV BHRF1 exerts its pro-survival function by directly inhibiting a sub-set of proapoptotic Bcl-2 family proteins Bid, Bim, Puma and Bak, presumably ones most critical for the virus. Our three-dimensional structures show that these interactions closely resemble those seen with mammalian pro-survival proteins such as Bcl- $\mathrm{x}_{\mathrm{L}}$. In light of the importance of BHRF1 in certain Burkitt lymphomas [9], and its detection in other EBV-associated malignancies including nasopharyngeal carcinoma [43] and B cell lymphomas [44], the development of therapeutic inhibitors of BHRF1 may be highly desirable. The inability of current small molecule inhibitors of 

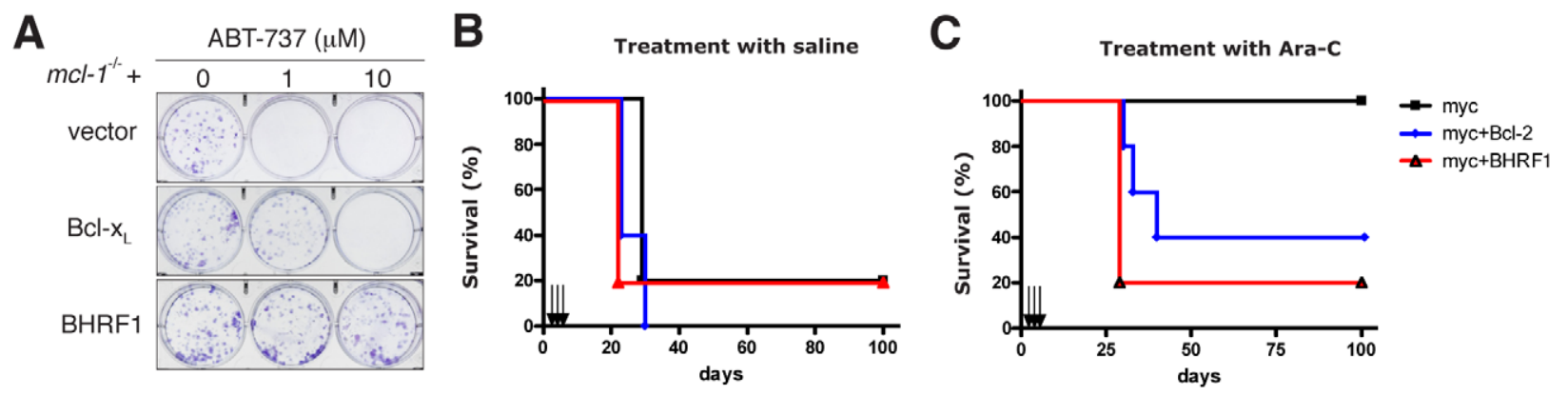

Figure 5. BHRF1 inhibits ABT-737 induced apoptosis and confers chemoresistance in a mouse model of Burkitt lymphoma. (A) Colony formation of $\mathrm{mcl}^{-1} 1^{-1-}$ MEFs overexpressing BHRF1, Bcl-x $\mathrm{L}$ or a control vector, $6 \mathrm{~d}$ after treatment with 0-10 $\mu \mathrm{M}$ ABT-737. (B, C) KaplanMeier survival plots of mice inoculated with E $\mu$-myc tumor cells overexpressing BHRF1, BCl-2 (or an empty vector) and treated on d 4, 5 and 6 (arrows) afterwards with (B) saline or (C) $100 \mathrm{mg} / \mathrm{kg}$ cytosine arabinoside (Ara-C; given intra-peritoneally). $\mathrm{N}=5$ mice in each group. Expression of BHRF1 or $\mathrm{Bcl}-2$ conferred chemoresistance ( $p=0.014$ and $p=0.049$ respectively by log-rank test when compared to saline treated controls). However, there is no significant difference whether or not BHRF1 or Bcl-2 is expressed as a transgene ( $p=0.85$ by log-rank test). doi:10.1371/journal.ppat.1001236.g005

mammalian pro-survival proteins such as ABT-737 to inhibit BHRF1 will require novel small molecule antagonists to be developed. The successful development of small molecule inhibitors of mammalian pro-survival Bcl-2 family proteins [40] suggests that similar approaches might be applied to the development of BHRF1 inhibitors.

\section{Materials and Methods}

\section{Recombinant proteins and binding experiments}

BHRF1 $\triangle \mathrm{C} 31$ was cloned into pET DUET (Invitrogen) using BamHI and EcoRI, and expressed in E.coli BL21 DE3 pLysS. Cells were homogenized using an Avestin EmulsiFlex homogenizer in lysis buffer (50 mM Tris-HCl, pH 8.0, $150 \mathrm{mM} \mathrm{NaCl,} 10 \mathrm{mM}$ BME). His-tagged BHRF1 $\Delta$ C31 was purified using a nickel charged HiTrap chelating column (Amersham), eluted in lysis buffer with $250 \mathrm{mM}$ imidazole and subjected to gel-filtration chromatography in 25 mM Hepes pH 7.5, 150 mM NaCl using a Superdex 200 column (GE Healthcare). Calorimetry data were collected on a VP-ITC (MicroCal) with BHRF1 $\Delta$ C31 as previously described [45]. All peptides were purified by reverse-phase HPLC and dissolved as 2$5 \mathrm{mM}$ stock solutions in water. The accession numbers for the peptides were: human Bim $_{\mathrm{L}}$ (AAC39594), human Puma (AAK39542), mouse Bmf (AAK38747), human Bad (NP_004313), human Bik (NP_001188), human Hrk (NP_003797), human Bid (NP_001187), human Noxa (NP_066950), human Bax (NP_620119), human Bak (NP_001179), mouse Mule (UniProt Accession code Q7TMY8; residues 1969-1994; PGGTTQEVGQLLQDMGDDVYQQYRSL) and mmBeclin (UniProt Accession code O88597, residue 103-128; DGGTMENLSRRLKVTGDLFDIMSGQT).

\section{Crystallization and structure determination}

BHRF1 complexes with Bim or Bak BH3 were obtained by mixing BHRF1 with human Bim or Bak 26-mer peptide in a 1:1.25 molar ratio and concentrating using a centricon (Millipore) to $10 \mathrm{mg} / \mathrm{mL}$. Crystals were grown in sitting drops at $20^{\circ} \mathrm{C}$ in $1.2 \mathrm{M} \mathrm{NaBr}, 50 \mathrm{mM}$ malic acid pH 4.0 (BHRF1:Bim) or $1.6 \mathrm{M}$ $\mathrm{NaNO}_{3}, 50 \mathrm{mM}$ malic acid pH 4.4 (BHRF1:Bak). The crystals belong to space group $\mathrm{P} 3{ }_{2} 21$ with $\mathrm{a}=\mathrm{b}=62.75 \AA$, $\mathrm{c}=92.38 \AA$, $\alpha=\beta=90^{\circ}, \gamma=120^{\circ}$ (BHRF1:Bim) or $\mathrm{a}=\mathrm{b}=62.39 \AA$ A, $\mathrm{c}=93.73$ $\AA, \alpha=\beta=90^{\circ}, \gamma=120^{\circ}$ (BHRF1:Bak). The asymmetric units contain 1 BHRF1:peptide complex. Diffraction data were collected from flash frozen crystals at $100 \mathrm{~K}$ at the Australian Synchrotron (beamline 3BM1) or at the Swiss Light Source (beamlines X06SA, X10SA) and processed with HKL2000. For the BHRF1:Bim complex, a heavy atom derivative was obtained by soaking crystals in mother liquor supplemented with $1 \mathrm{mM}$ $\mathrm{MeHgCl}$ for $2 \mathrm{~h}$. $\mathrm{Hg}$ sites were found and refined with Sharp. Clear and continuous electron density was obtained for residues $2-$ 158 of BHRF1 and 51-72 of Bim. The final model was built with Coot [46], refined with Refmac5 [47] to a resolution of $1.5 \AA$ and has a final R-factor of 0.198 (R-free 0.205 ). $95.0 \%$ of the residues are in the core regions of the Ramachandran plot, and no residues are in disallowed regions.

The BHRF1:Bak structure was solved by molecular replacement with PHASER [48] using the BHRF1:Bim structure as a search model. The final model was built with Coot and refined with Refmac5 to a resolution of $2.05 \AA$ and has a final R-factor of 0.184 (R-free 0.217 ). $97.4 \%$ of the residues are in the core regions of the Ramachandran plot, and no residues are in disallowed regions. All data collection and refinement statistics are summarized in Table 1. The coordinates have been deposited in the Protein Data Bank (accession codes 2v6q, 2wh6, 2xpx). Figures were prepared using PyMol (DeLano Scientific).

\section{Mouse tumor model}

E $\mu-m y c$ transgenic mice on an inbred C57BL/6 background with clinical evidence of lymphoma were culled by $\mathrm{CO}_{2}$ asphyxiation and lymphomatous tissue excised. Single-cell suspensions were obtained by manual sieving and stable E $\mu-m y c$ tumor cell cultures were established in FMA medium. Retroviral transduction using a pMSCV-IRES-GFP vector containing BHRF1 or Bcl-2 and sorting of GFP positive cells were conducted as previously described [11]. $1 \times 10^{6}$ viable tumor cells in $100 \mu \mathrm{L}$ PBS were injected intraperitoneally into syngeneic C57BL/6 mice. Ara-C or PBS was injected intraperitoneally in $100 \mu \mathrm{L}$ total volume on days 4, 5 and 6 . Mice were culled when sick (hindleg paralysis, tremor, lethargic, tumor nodule $>1 \mathrm{~cm}$ diameter, $>5 \%$ weight loss) and leukemia/lymphoma confirmed by the presence of peripheral blood leucocytosis and enlarged spleen and/or lymph nodes. Survival of cohorts of 5 mice was compared by logrank test and Kaplan-Meier analysis using GraphPad Prism statistical software. All experiments were approved by an institutional ethics committee.

\section{Cell lines and tissue culture}

MEF, HEK-293T and Phoenix packaging 293 cells were cultured in Dulbecco's Modified Eagles medium (DMEM) 
supplemented with $10 \%$ FCS. FDC-P1 cells were additionally supplemented with mouse IL-3 (1000 U/mL). E $\mu$-myc tumor cells were harvested from a symptomatic E $\mu$-myc transgenic mouse and cultured in FMA, a high glucose version of DMEM supplemented with $10 \%$ FCS, $50 \mu \mathrm{M} 2$-mercaptoethanol and $250 \mu \mathrm{M}$ asparagine.

\section{Mammalian expression constructs}

Epitope-tagged mammalian expression vectors for human Bcl-2 family proteins have been described previously [20,49,50,51,52]. All constructs were verified by sequencing. Details and constructs are available from the authors.

\section{Retrovirus production and transduction}

To produce retroviral supernatant, $2.5 \times 10^{6}$ ecotropic Phoenix packaging cells were seeded overnight in $10 \mathrm{~cm}$ tissue culture plates. Media was replaced with $5 \mathrm{ml}$ serum-free DMEM containing $5 \mu \mathrm{g}$ MSCV-based retroviral plasmid with $15 \mu \mathrm{L}$ Lipofectamine (Invitrogen). After $24 \mathrm{~h}$ media was replaced with medium supplemented with 20\% FCS and incubated for a further $24 \mathrm{~h}$ at $32^{\circ} \mathrm{C}$. Viral supernatant was cleared of cell debris by centrifugation for $5 \mathrm{~min}$ at $1500 \mathrm{rpm}$. $500 \mu \mathrm{L}$ filtered virus $(0.45 \mu \mathrm{m}$, Millipore) was spin-infected onto target cells in a total volume of $1 \mathrm{~mL}$ media containing $4 \mu \mathrm{g} / \mathrm{mL}$ polybrene (Sigma) in 24 well plates at $32^{\circ} \mathrm{C}$ with $2500 \mathrm{rpm}$ radial centrifugation for $45 \mathrm{~min}$. Infection efficiency of MEFs were generally $>90 \%$ and 20-30\% for FDC-P1 cells.

\section{Cell survival assays and cytotoxic drugs}

Cell death was induced by $0-100 \mu \mathrm{M}$ etoposide (PharmaciaUpjohn), 0-30 Gy $\gamma$-irradiation, 0-10 $\mu \mathrm{M}$ Ara C (PharmaciaUpjohn), 0-100 nM staurosprorine (Sigma-Aldrich) or 0-10 $\mu \mathrm{M}$ ABT-737 (Abbott Laboratories). Cell viability was quantified by flow cytometric analysis of cells excluding $5 \mu \mathrm{g} / \mathrm{mL}$ propidium iodide (PI) (Sigma-Aldrich) using a FACScan (Becton Dickinson). Each time point was performed at least three times. For long-term colony assays using MEFs, cells were infected with GFP-expressing retroviral constructs, then treated with qVD.OPH (Enzyme Systems) to prevent cell death. After culture for 24 h, $200 \mathrm{GFP}^{+\mathrm{ve}}$ cells were sorted into 6 -well plates. Colonies were stained and counted $6 \mathrm{~d}$ later.

\section{Immunofluorescence}

Cells expressing mammalian FLAG-tagged pro-survival Bcl-2 proteins, BHRF1 or empty vector were washed in PBS, fixed in $1 \%$ paraformaldehyde/PBS $\left(10 \mathrm{~min}, 4^{\circ} \mathrm{C}\right)$ and washed twice in KDS-BSS. Cells were incubated with 1:1,000 primary anti-FLAG M2 (Sigma) antibody for 20 minutes, washed in KDS-BSS/0.02\% saponin and then incubated with 1:100 goat anti-mouse FITC or PE antibody (Southern Biotechnology) for 20 minutes before analysis on a FACScan (BD) using Cell Quest software (BD).

\section{Cytofluorometric determination of mitochondrial transmembrane potential and Bax/Bak activation}

To assess mitochondrial transmembrane potential $(\Delta \psi \mathrm{m})$, cells were incubated for $15 \mathrm{~min}$ at $37^{\circ} \mathrm{C}$ in buffer containing $40 \mathrm{nM}$ 3,3'- dihexyloxacarbocyanine iodide (DiOC6[3]; Molecular Probes) before adding $10 \mu \mathrm{g} / \mathrm{mL}$ of PI. The cells were kept on ice until flow cytometric analysis. To assess the activation of Bax and Bak, HeLa cells were left untreated or pretreated with a proteasome inhibitor (10 $\mu \mathrm{M}$ MG-132; Calbiochem) or a widespectrum caspase inhibitor (100 $\mu \mathrm{M} z \mathrm{zAD}$.fmk; Bachem) for $1 \mathrm{~h}$ before treatment with $200 \mathrm{~J} / \mathrm{m}^{2} \mathrm{UV}$-irradiation. Following UV irradiation, cells were fixed with $1 \%$ paraformaldehyde $(5 \mathrm{~min}$ at room temperature) and then washed with buffer supplemented with $2 \%$ fetal bovine serum. Fixed cells were then incubated with the primary antibodies: $2 \mu \mathrm{g} / \mathrm{mL}$ anti-Bak Ab-1 (Calbiochem) or $5 \mu \mathrm{g} / \mathrm{mL}$ anti-Bax clone 3 (BD) diluted in FACS buffer supplemented with $0.3 \%$ saponin for $30 \mathrm{~min}$ on ice. Cells were then washed, before incubation with the appropriate secondary antibody, either FITC-conjugated goat-anti-mouse IgG $(10 \mu \mathrm{g} /$ $\mathrm{ml}$; SouthernBiotech) to detect Bax activation or a biotinconjugated anti-mouse (diluted 1:200; SouthernBiotech) followed by Streptavidin-conjugated PE (diluted 1:300; Caltag) to detect Bak activation. The samples were analyzed using a FACScan (BD).

\section{Subcellular fractionation}

Fractionation of whole cell lysates into the soluble and pellet fractions has been previously described [54]. In brief, cells lysed in HMKEE buffer (20 mM Hepes, pH 7.2, 5 mM MgCl2, $10 \mathrm{mM}$ $\mathrm{KCl}, 1 \mathrm{mM}$ EDTA, $1 \mathrm{mM}$ EGTA, and protease inhibitors) containing $250 \mathrm{mM}$ sucrose and $0.025 \%$ digitonin (Calbiochem) were left on ice for $10 \mathrm{~min}$, and then the organelles, cytoskeleton, and membranes were pelleted by centrifugation $(13,000 \mathrm{rpm}$, $5 \mathrm{~min}$ at $\left.4^{\circ} \mathrm{C}\right)$. The pellet was solubilized in RIPA buffer $(150 \mathrm{mM}$ $\mathrm{NaCl}, 1 \%$ Triton X-100, 0.5\% deoxycholic acid, $0.1 \%$ SDS, $50 \mathrm{mM}$ Tris-HCl, $\mathrm{pH}$ 8.0, and protease inhibitors). The protease inhibitors used include Pefabloc SC, soybean trypsin inhibitor, leupeptin, aprotinin, E64, and pepstatin (Sigma-Aldrich or Roche).

\section{Transient transfection, immunoprecipitation and immunoblotting}

The transfection and metabolic labeling of HEK-293T cells with ${ }^{35}$ S-methionine/cysteine (NEN) as well as co-immunoprecipitation have been described $[49,50,52]$. Briefly, equivalent TCAprecipitable lysates were immunoprecipiated using the mouse monoclonal antibodies to FLAG (M2; Sigma), Glu-Glu (CRP) and control HA (HA.11; GRP) tags. The proteins were resolved by SDS:PAGE, transferred onto nitrocellulose membranes and detected by autoradiography after $20 \mathrm{~h}$ at $-80^{\circ} \mathrm{C}$. Immunoblotting was performed using mouse monoclonal antibodies to Bax (5B7; Sigma-Aldrich) cytochrome c (7H8.2C12; BD Pharmingen) and detected using HRP-conjugated secondary antibodies (Southern Biotechnology) revealed by enhanced chemiluminescence (ECL; Amersham Biosciences).

\section{Yeast colony assays}

Yeast expression vectors were made by subcloning the cDNAs for full-length human Bcl- $\mathrm{x}_{\mathrm{L}}$ and BHRF1, or human Bax and human Bak, respectively, into the pGALL(TRP1) and pGALS(LEU2) vectors [55]. Saccharomyces cerevisiae W303a cells were cotransformed with indicated plasmids and grown under selection. For the survival assays, the cells were spotted as 5-fold serial dilutions onto glucose (repressing, "OFF") or galactose (inducing, "ON") plates as previously described [28]. Plates were incubated for $48 \mathrm{~h}$ at $30^{\circ} \mathrm{C}$ and then photographed.

\section{Ethics statement}

This study was carried out in strict accordance with the recommendations in the Guide for the Care and Use of Laboratory Animals of the National Health and Medical Research Council. The protocol was approved by the Committee on the Ethics of Animal Experiments of the Walter and Eliza Hall Institute of Medical Research (Permit Number: NKOT_07_008). 
All surgery was performed under sodium pentobarbital anesthesia, and all efforts were made to minimize suffering.

\section{Supporting Information}

Figure S1 Pre-B-cell tumor cells derived from E $\mu$-myc transgenic mice were stably transfected with BHRF1, Bcl-2 or a control vector and exposed to etoposide $(0-10 \mu \mathrm{M})$. Viability was assessed by PI staining after $24 \mathrm{~h}$.

Found at: doi:10.1371/journal.ppat.1001236.s001 (0.17 MB TIF)

Figure S2 BHRF1 is not inhibited by ABT-737. Mcl-1 deficient MEF stably expressing BHRF1, Bcl $x_{\mathrm{L}}$ or a control vector were treated with ABT-737 $(0-10 \mu \mathrm{M})$. Viability was assessed $8 \mathrm{~h}$ later by flow cytometry after propidium iodide staining.

Found at: doi:10.1371/journal.ppat.1001236.s002 (0.13 MB TIF)

\section{References}

1. Galluzzi L, Brenner C, Morselli E, Touat Z, Kroemer G (2008) Viral control of mitochondrial apoptosis. PLoS Pathog 4: e1000018.

2. Cuconati A, White E (2002) Viral homologs of BCL-2: role of apoptosis in the regulation of virus infection. Genes and Development 16: 2465-2478.

3. Cuconati A, Degenhardt K, Sundararajan R, Anschel A, White E (2002) Bak and Bax function to limit adenovirus replication through apoptosis induction. J Virol 76: 4547-4558.

4. Marchini A, Tomkinson B, Cohen JI, Kieff E (1991) BHRF1, the Epstein-Barr virus gene with homology to $\mathrm{Bc} 12$, is dispensable for B-lymphocyte transformation and virus replication. J Virol 65: 5991-6000.

5. Henderson S, Huen D, Rowe M, Dawson C, Johnson G, et al. (1993) EpsteinBarr virus-coded BHRF1 protein, a viral homologue of Bcl-2, protects human B cells from programmed cell death. Proc Natl Acad Sci U S A 90: 8479-8483.

6. Thorley-Lawson DA, Gross A (2004) Persistence of the Epstein-Barr virus and the origins of associated lymphomas. N Engl J Med 350: 1328-1337.

7. Tsujimoto Y, Cossman J, Jaffe E, Croce CM (1985) Involvement of the bcl-2 gene in human follicular lymphoma. Science 228: 1440-1443.

8. Altmann M, Hammerschmidt W (2005) Epstein-Barr virus provides a new paradigm: a requirement for the immediate inhibition of apoptosis. PLoS Biol 3: e404.

9. Kelly GL, Long HM, Stylianou J, Thomas WA, Leese A, et al. (2009) An Epstein-Barr virus anti-apoptotic protein constitutively expressed in transformed cells and implicated in burkitt lymphomagenesis: the Wp/BHRF1 link. PLoS Pathog 5: e1000341.

10. Taub R, Kirsch I, Morton C, Lenoir G, Swan D, et al. (1982) Translocation of the c-myc gene into the immunoglobulin heavy chain locus in human Burkitt lymphoma and murine plasmacytoma cells. Proc Natl Acad Sci U S A 79: 7837-7841.

11. Adams JM, Harris AW, Pinkert CA, Corcoran LM, Alexander WS, et al. (1985) The c-myc oncogene driven by immunoglobulin enhancers induces lymphoid malignancy in transgenic mice. Nature 318: 533-538.

12. Magrath I (1990) The pathogenesis of Burkitt's lymphoma. Adv Cancer Res 55: $133-270$.

13. Strasser A, Harris AW, Bath ML, Cory S (1990) Novel primitive lymphoid tumours induced in transgenic mice by cooperation between myc and bcl-2. Nature 348: 331-333.

14. Beverly LJ, Varmus HE (2009) MYC-induced myeloid leukemogenesis is accelerated by all six members of the antiapoptotic BCL family. Oncogene 28: 1274-1279.

15. Kelly G, Bell A, Rickinson A (2002) Epstein-Barr virus-associated Burkitt lymphomagenesis selects for downregulation of the nuclear antigen EBNA2. Nat Med 8: 1098-1104.

16. Green DR, Kroemer G (2004) The pathophysiology of mitochondrial cell death. Science 305: 626-629.

17. Cross JR, Postigo A, Blight K, Downward J (2008) Viral pro-survival proteins block separate stages in Bax activation but changes in mitochondrial ultrastructure still occur. Cell Death Differ 15: 997-1008.

18. Flanagan AM, Letai A (2008) BH3 domains define selective inhibitory interactions with BHRF-1 and KSHV BCL-2. Cell Death Differ 15: 580-588.

19. Uren RT, Dewson G, Chen L, Coyne SC, Huang DC, et al. (2007) Mitochondrial permeabilization relies on $\mathrm{BH} 3$ ligands engaging multiple prosurvival Bcl-2 relatives, not Bak. J Cell Biol 177: 277-287.

20. Chen L, Willis SN, Wei A, Smith BJ, Fletcher JI, et al. (2005) Differential targeting of pro-survival $\mathrm{Bcl}-2$ proteins by their $\mathrm{BH} 3$-only ligands allows complementary apoptotic function. Molecular Cell 17: 393-403.

21. Willis SN, Fletcher JI, Kaufmann T, van Delft MF, Chen L, et al. (2007) Apoptosis initiated when BH3 ligands engage multiple Bcl-2 homologs, not Bax or Bak. Science 315: 856-859.

\section{Acknowledgments}

We thank many colleagues including J Adams, P Bouillet, S Cory, G Dewson, the late A. Harris, R Kluck, G Kelly and A Strasser for discussions; F Battye, J Beaumont, J Blyth, H Ierino, V Lapatis, S Meusburger, F Tan for technical assistance; N Iannarella, J Morrow, A Naughton, K McKenzie for animal care; Abbott Laboratories (S Rosenberg and colleagues), the late A Harris, P Kelly, the late S Korsmeyer, L O'Reilly, A Strasser, M van Delft for reagents; staff at the Australian Synchrotron and the Swiss Light Source for help with data collection; and the Bio21 C3 Centre for help with crystallization.

\section{Author Contributions}

Conceived and designed the experiments: MK AHW JIF AWR DCSH PMC. Performed the experiments: MK AHW JIF SNW LG. Analyzed the data: MK AHW JIF LG DGSH PMC. Contributed reagents/materials/ analysis tools: SNW AWR DCSH. Wrote the paper: MKJIF DCSH PMC.

22. Cartron PF, Gallenne T, Bougras G, Gautier F, Manero F, et al. (2004) The first alpha helix of Bax plays a necessary role in its ligand-induced activation by the BH3-only proteins Bid and PUMA. Molecular Cell 16: 807-818.

23. Kuwana T, Bouchier-Hayes L, Chipuk JE, Bonzon C, Sullivan BA, et al. (2005) BH3 Domains of BH3-Only Proteins Differentially Regulate Bax-Mediated Mitochondrial Membrane Permeabilization Both Directly and Indirectly. Molecular Cell 17: 525-535.

24. Letai A, Bassik M, Walensky L, Sorcinelli M, Weiler S, et al. (2002) Distinct BH3 domains either sensitize or activate mitochondrial apoptosis, serving as prototype cancer therapeutics. Cancer Cell 2: 183-192.

25. Oltvai ZN, Milliman CL, Korsmeyer SJ (1993) Bcl-2 heterodimerizes in vivo with a conserved homolog, Bax, that accelerates programmed cell death. Cell 74: 609-619.

26. White E, Sabbatini P, Debbas M, Wold WSM, Kusher DI, et al. (1992) The 19kilodalton adenovirus E1B transforming protein inhibits programmed cell death and prevents cytolysis by tumor necrosis factor $\alpha$. Molecular and Cellular Biology 12: 2570-2580.

27. Kvansakul M, van Delft MF, Lee EF, Gulbis JM, Fairlie WD, et al. (2007) A structural viral mimic of prosurvival bcl-2: a pivotal role for sequestering proapoptotic bax and bak. Molecular Cell 25: 933-942.

28. Jabbour AM, Puryer MA, Yu JY, Lithgow T, Riffkin CD, et al. (2006) Human Bcl-2 cannot directly inhibit the Caenorhabditis elegans Apaf-1 homologue CED-4, but can interact with EGL-1. J Cell Sci 119: 2572-2582.

29. Hsu YT, Youle RJ (1997) Nonionic detergents induce dimerization among members of the Bcl-2 family. J Biol Chem 272: 13829-13834.

30. Tao W, Kurschner C, Morgan JI (1997) Modulation of cell death in yeast by the Bcl-2 family of proteins. J Biol Chem 272: 15547-15552.

31. Desbien AL, Kappler JW, Marrack P (2009) The Epstein-Barr virus Bcl-2 homolog, BHRF1, blocks apoptosis by binding to a limited amount of Bim. Proc Natl Acad Sci U S A 106: 5663-5668.

32. Theodorakis P, D'Sa-Eipper C, Subramanian T, Chinnadurai G (1996) Unmasking of a proliferation-restraining activity of the anti-apoptosis protein EBV BHRF1. Oncogene 12: 1707-1713.

33. Bouillet P, Metcalf D, Huang DCS, Tarlinton DM, Kay TWH, et al. (1999) Proapoptotic Bcl-2 relative Bim required for certain apoptotic responses, leukocyte homeostasis, and to preclude autoimmunity. Science 286: 1735-1738.

34. Egle A, Harris AW, Bouillet P, Cory S (2004) Bim is a suppressor of Mycinduced mouse B cell leukemia. Proc Natl Acad Sci U S A 101: 6164-6169.

35. Huang Q, Petros AM, Virgin HW, Fesik SW, Olejniczak ET (2003) Solution structure of the BHRF1 protein from Epstein-Barr virus, a homolog of human Bcl-2. Journal of Molecular Biology 332: 1123-1130.

36. Liu X, Dai S, Zhu Y, Marrack P, Kappler JW (2003) The structure of a Bcl- $\mathrm{x}_{\mathrm{L}}$ / Bim fragment complex: Implications for Bim function. Immunity 19: 341-352.

37. Muchmore SW, Sattler M, Liang H, Meadows RP, Harlan JE, et al. (1996) Xray and NMR structure of human $\mathrm{Bcl}-\mathrm{x}_{\mathrm{L}}$, an inhibitor of programmed cell death. Nature 381: 335-341.

38. Czabotar PE, Lee EF, van Delft MF, Day CL, Smith BJ, et al. (2007) Structural insights into the degradation of Mcl-1 induced by BH3 domains. Proc Natl Acad Sci U S A 104: 6217-6222.

39. Lee EF, Sadowsky JD, Smith BJ, Czabotar PE, Peterson-Kaufman KJ, et al. (2009) High-resolution structural characterization of a helical alpha/betapeptide foldamer bound to the anti-apoptotic protein Bcl-xL. Angew Chem Int Ed Engl 48: 4318-4322.

40. Oltersdorf T, Elmore SW, Shoemaker AR, Armstrong RC, Augeri DJ, et al. (2005) An inhibitor of Bcl-2 family proteins induces regression of solid tumours. Nature 435: 677-681.

41. van Delft MF, Wei AH, Mason KD, Vandenberg CJ, Chen L, et al. (2006) The BH3 mimetic ABT-737 targets selective Bcl-2 proteins and efficiently induces apoptosis via Bak/Bax if Mcl-1 is neutralized. Cancer Cell 10: 389-399. 
42. Schmitt CA, Rosenthal CT, Lowe SW (2000) Genetic analysis of chemoresistance in primary murine lymphomas. Nat Med 6: 1029-1035.

43. Liu MY, Shih YY, Li LY, Chou SP, Sheen TS, et al. (2000) Expression of the Epstein-Barr virus BHRF1 gene, a homologue of Bcl-2, in nasopharyngeal carcinoma tissue. J Med Virol 61: 241-250.

44. Oudejans JJ, van den Brule AJ, Jiwa NM, de Bruin PC, Ossenkoppele GJ, et al. (1995) BHRF1, the Epstein-Barr virus (EBV) homologue of the BCL-2 protooncogene, is transcribed in EBV-associated B-cell lymphomas and in reactive lymphocytes. Blood 86: 1893-1902.

45. Kvansakul M, Yang H, Fairlie WD, Czabotar PE, Fischer SF, et al. (2008) Vaccinia virus anti-apoptotic F1L is a novel Bcl-2-like domain-swapped dimer that binds a highly selective subset of BH3-containing death ligands. Cell Death Differ 15: 1564-1571.

46. Emsley P, Cowtan K (2004) Coot: model-building tools for molecular graphics. Acta Crystallogr D Biol Crystallogr 60: 2126-2132.

47. Murshudov GN, Vagin AA, Dodson EJ (1997) Refinement of macromolecular structures by the maximum-likelihood method. Acta Crystallogr D Biol Crystallogr 53: 240-255.

48. Storoni LC, McCoy AJ, Read RJ (2004) Likelihood-enhanced fast rotation functions. Acta Crystallogr D Biol Crystallogr 60: 432-438.

49. O'Connor L, Strasser A, O'Reilly LA, Hausmann G, Adams JM, et al. (1998) Bim: a novel member of the Bcl-2 family that promotes apoptosis. Embo J 17: 384-395.
50. Moriishi K, Huang DC, Cory S, Adams JM (1999) Bcl-2 family members do not inhibit apoptosis by binding the caspase activator Apaf-1. Proc Natl Acad Sci U S A 96: 9683-9688.

51. Fletcher JI, Meusburger S, Hawkins CJ, Riglar DT, Lee EF, et al. (2008) Apoptosis is triggered when prosurvival Bcl-2 proteins cannot restrain Bax. Proc Natl Acad Sci U S A 105: 18081-18087.

52. Huang DC, O'Reilly LA, Strasser A, Cory S (1997) The anti-apoptosis function of Bcl-2 can be genetically separated from its inhibitory effect on cell cycle entry. Embo J 16: 4628-4638.

53. Dewson G, Snowden RT, Almond JB, Dyer MJ, Cohen GM (2003) Conformational change and mitochondrial translocation of Bax accompany proteasome inhibitor-induced apoptosis of chronic lymphocytic leukemic cells. Oncogene 22: 2643-2654.

54. Wilson-Annan J, O'Reilly LA, Crawford SA, Hausmann G, Beaumont JG, et al. (2003) Proapoptotic BH3-only proteins trigger membrane integration of prosurvival Bcl-w and neutralize its activity. J Cell Biol 162: 877-887.

55. Hawkins CJ, Wang SL, Hay BA (1999) A cloning method to identify caspases and their regulators in yeast: identification of Drosophila IAP1 as an inhibitor of the Drosophila caspase DCP-1. Proc Natl Acad Sci U S A 96: 2885-2890.

56. Zha J, Harada H, Osipov K, Jockel J, Waksman G, et al. (1997) BH3 domain of $\mathrm{BAD}$ is required for heterodimerization with BCL-XL and pro-apoptotic activity. J Biol Chem 272: 24101-24104. 